\title{
SISTEM PAKAR UNTUK MENDIAGNOSA KECENDERUNGAN PERILAKU ABNORMAL PADA ANAK-ANAK MENGGUNAKAN METODE BAYES
}

\author{
M. Irwan Ukkas ${ }^{1)}$, Ekawati Yulsilviana ${ }^{2)}$, Siti Aisyah ${ }^{3)}$ \\ ${ }^{1,3}$ Sistem Informasi, STMIK Widya Cipta Dharma \\ ${ }^{2}$ Manajemen Informatika,STMIK Widya Cipta Dharma \\ $1,2,3$ Jl. Prof. M. Yamin No. 25, Samarinda, 75123 \\ E-mail : Irwan212@yahoo.com ${ }^{1)}$, ekawati_stmik@yahoo.com ${ }^{2)}$,informatikawicida@gmail.com ${ }^{3)}$,
}

\begin{abstract}
ABSTRAK
Perilaku abnormal adalah suatu perilaku yang menunjukan aspek kepribadian, aspek perilaku yang dapat langsung diamati. Menunjuk pada perilaku maladaptif yaitu setiap perilaku yang mempunyai dampak merugikan bagi individu atau masyarakat. Memiliki gangguan mental pada semua bentuk perilaku abnormal mulai dari yang ringan sampai yang terberat. Mencakup penyakit jiwa yakni mengalami gangguan-gangguan yang melibatkan patologi otak atau berupa disorganisasi kepribadian yang parah. Diagnosa kecenderuan perilaku abnormal untuk sekarang ini dilakukan berdasarkan kriteria yang ditetapkan terlebih dahulu oleh ahli psikologi, yaitu psikolog.

Penelitian ini dilakukan pada SLB Cemara Wilis Samarinda, Dalam pengumpulan data pada penelitian ini dilakukan studi pustaka dan wawancara, adapun alat bantu yang digunakan adalah bagan alur program (program flowchart) dan Decession table dengan bahasa pemrogramman yang digunakan adalah Microsoft Visual Basic 6.0, dan cara pengujiannya menggunakan pengujian Black Box.

Hasil dari penelitian ini yakni dengan dibanngunnya Sistem Pakar Diagnosa kecenderungan perilaku abnormal, yang menghasilkan jenis gangguan, bagaimana solusi pengobatannya, laporan tentang pasien dan utuk memfasilitasi guru dan masyarakat dalam mendiagnosa kecenderungan perilaku abnormal pada anak-anak.
\end{abstract}

Kata Kunci: Sistem Pakar, Diagnosa, Perilaku Abnormal, Anak-anak, Bayes

\section{PENDAHULUAN}

Perilaku abnormal adalah suatu perilaku yang menunjukan aspek kepribadian, aspek perilaku yang dapat langsung diamati. Abnormalitas dilihat dari sudut pandang biologis berawal dari pendapat bahwa patologi otak merupakan faktor penyebab tingkah laku abnormal.

Kemajuan teknologi informasi telah banyak mempengaruhi perkembangan diberbagai bidang, termasuk bidang psikologi. Permasalahan-permasalahan di atas dapat di atasi dengan cara membangun sebuah sistem berbasis komputer yang dapat menampung pengetahuan psikolog.

Sistem pakar untuk mendiagnosa kecenderungan perilaku abnormal ini dapat membantu pihak sekolah atau masyarakat yang mengalami kecenderungan perilaku abnormal. Mereka bisa melakukan konsultasi dirumah ataupun di sekolah tanpa harus datang atau berkonsultasi langsung dengan psikolog sehingga bisa menekan pengeluaran dan tidak merasa malu dengan masyarakat sekitar.

\section{RUANG LINGKUP PENELITIAN}

Permasalahan difokuskan pada:

1. Mendiagnosa kecenderungan perilaku abnormal

2. Mendiagnosa perilaku abnormal pada anak-anak
3. Output yang di hasilkan adalah data anak, jenis gangguan dan solusi atau cara pencegahannya.

\section{BAHAN DAN METODE}

Berikut adalah metode dan bahan pengembangan sistem ini.

\subsection{Metode Forward Chaining}

Runut maju berarti menggunakan himpunan aturan kondisi-kondisi, yang Dalam metode ini data di gunakan untuk menentukan aturan mana yang akan di jalankan (Supratikya, 2006)

\subsection{Teori Bayes}

Probabilitas Bayesian adalah suatu interpretasi dari kalkulus yang memuat konsep probabilitas sebagai derajat dimana suatu pernyataan dipercaya benar.

Teori probabilitas Bayes merupakan satu dari cabang teori statistik matematik yang memungkinkan kita untuk membuat satu model ketidakpastian dari suatu kejadian yang terjadi dengan menggabungkan pengetahuan umum dengan fakta dari hasil pengamatan. 


\section{RANCANGAN SISTEM/APLIKASI}

Gambar dibawah menjelaskan bahwa pada saat user menggunakan aplikasi ini, maka ada form yang mengharuskan user memilih apakah sebagai pakar atau user biasa,Apabila pengguna aplikasi ini berstatus sebagai user biasa maka pengguna hanya dapat melakukan pengisian data pasien serta proses pelacakan gangguan perilaku dengan memilih gejala-gejala yang telah disediakan untuk mendiagnosa gangguan apa yang ada pada pasien,kemudian dari proses tersebut akan menghasilkan jenis atau nama gangguan beserta saran untuk mengatasi gangguan tersebut.

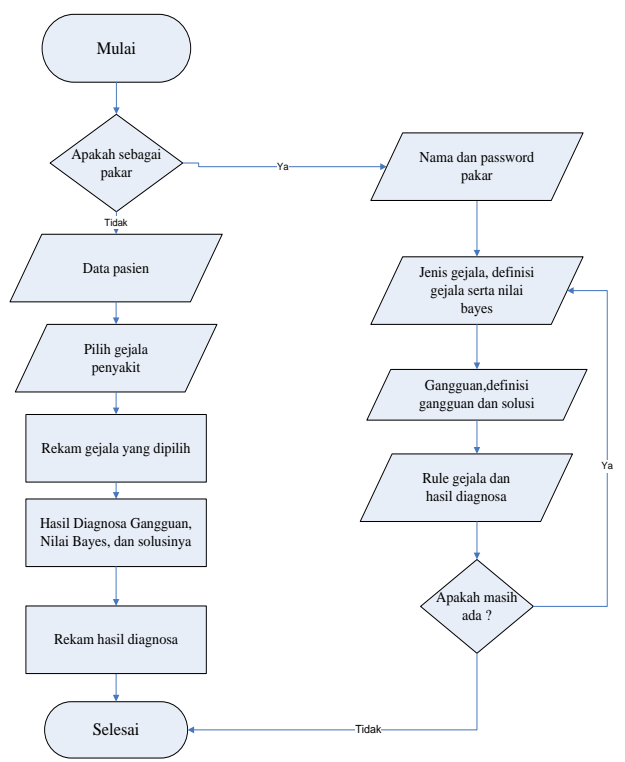

Gambar 1. Flowchart user dan flowchart pakar

\section{Struktur Basis Data}

Tabel 1. Struktur Tabel Pasien

\begin{tabular}{|c|c|c|c|}
\hline No & $\begin{array}{c}\text { Nama } \\
\text { Field }\end{array}$ & Tipe Data & Keterangan \\
\hline 1 & Idpasien & Text (5) & Id pasien \\
\hline 2 & Tgl & Date/time & Tanggal pendataan pasien \\
\hline 3 & Nm & Text (50) & Nama pasien \\
\hline 4 & Usia & Text (3) & Usia pasien \\
\hline 5 & Jk & Text (25) & Jenis kelamin \\
\hline 6 & Almt & Text (150) & Alamat \\
\hline 7 & NmOrtu & Text (50) & Nama orang tua \\
\hline
\end{tabular}

Tabel 2. Struktur Tabel Jenis Gejala

\begin{tabular}{|c|c|c|c|}
\hline No & $\begin{array}{c}\text { Nama } \\
\text { Field }\end{array}$ & Tipe Data & Keterangan \\
\hline 1 & Nojenis & Text (4) & No gejala \\
\hline 2 & Jenis & Memo & Nama Jenis gejala \\
\hline 3 & Def & Memo & Keterangan gejala \\
\hline 4 & Nil & Text (4) & Nilai bobot gejala \\
\hline
\end{tabular}

Tabel 3. Struktur Tabel Gangguan

\begin{tabular}{|c|c|c|c|}
\hline No & Nama Field & $\begin{array}{c}\text { Tipe } \\
\text { Data }\end{array}$ & Keterangan \\
\hline 1 & Nopeny & Text (5) & No gangguan \\
\hline 2 & Peny & Memo & Nama gangguan \\
\hline 3 & $\begin{array}{c}\text { Penjelasanpe } \\
\text { ny }\end{array}$ & Memo & $\begin{array}{c}\text { Keterangan } \\
\text { gangguan }\end{array}$ \\
\hline 4 & Solusi & Memo & Solusi / terapi \\
\hline
\end{tabular}

Tabel 4. Struktur Tabel Hasil Diagnosa

\begin{tabular}{|c|c|c|c|}
\hline No & Nama Field & Tipe Data & Keterangan \\
\hline 1 & Idpasien & Text (5) & Id pasien \\
\hline 2 & Tgl & Date/Time & Tanggal diagnosa \\
\hline 3 & Nm & Text (50) & Nama pasien \\
\hline 4 & Jk & Text (20) & Jenis kelamin \\
\hline 5 & Usia & Text (3) & Usia \\
\hline 6 & Almt & Text (150) & Alamat \\
\hline 7 & NmOrtu & Text (50) & Nama orang tua \\
\hline 8 & Rekampeny & Memo & Rekam data gangguan \\
\hline 9 & Defpeny & Text (150) & Keterangan gangguan \\
\hline 10 & Hasil & Memo & $\begin{array}{c}\text { Hasil diagnosa dan } \\
\text { solusi }\end{array}$ \\
\hline 11 & Nilai & Text (4) & Nilai probabilitas \\
\hline
\end{tabular}

\section{IMPLEMENTASI}

Berikut adalah hasil implementasi sistem yang telah dihasilkan

1. login pakar

Halaman ini merupakan tampilan form login untuk pakar

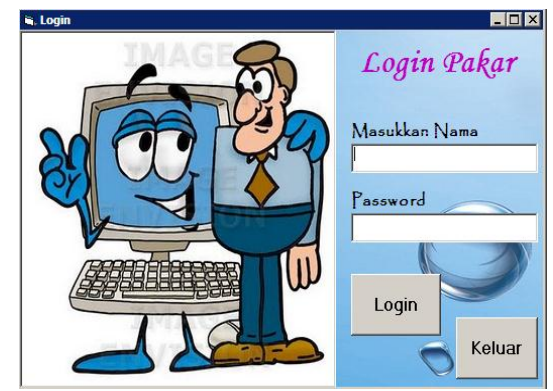

Gambar 2. Tampilan Login Pakar

\section{Menu Utama}

Menu utama ini terdiri dari Admin, Pakar dan info sistem

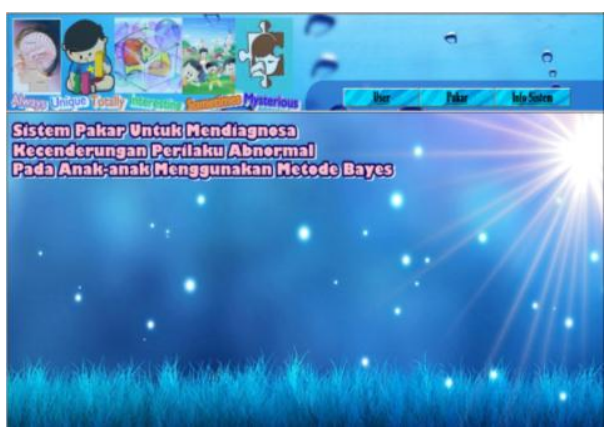

Gambar 3. Tampilan Menu Utama 


\section{Form Gejala}

Form untuk memasukkan data gejala yang ada pada perilaku abnormal

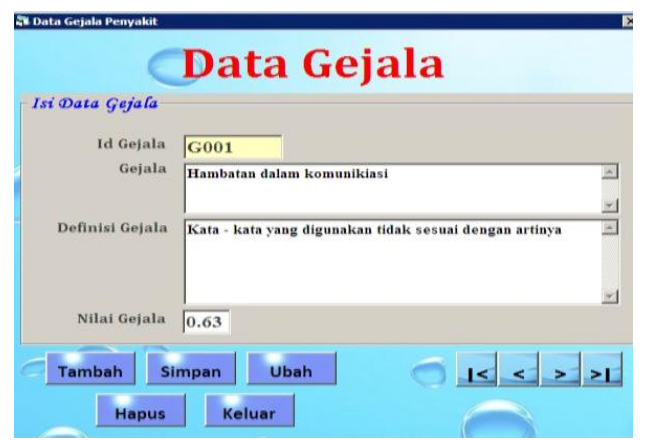

Gambar 4. Tampilan Form Gejala

\section{Form Gangguan}

Form untuk memasukkan data gangguan yang ada pada perilaku abnormal

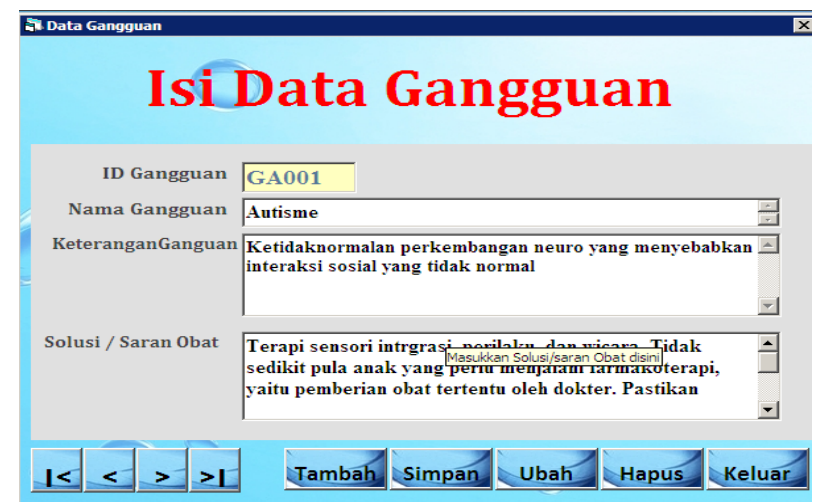

Gambar 5. Tampilan Form Gangguan

\section{Form Aturan}

Form untuk menginput data aturan. Data gejala dan gangguan telah diinput sebelumnya kemudian muncul di form aturan lalu direlasikan

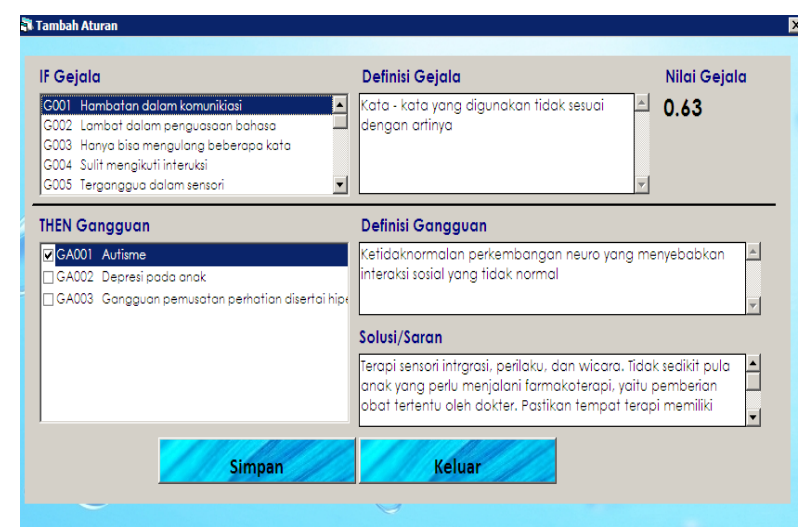

Gambar 6. Tampilan Form Aturan

\section{Form Pasien}

Form data pasien berfungsi untuk memasukkan data pasien

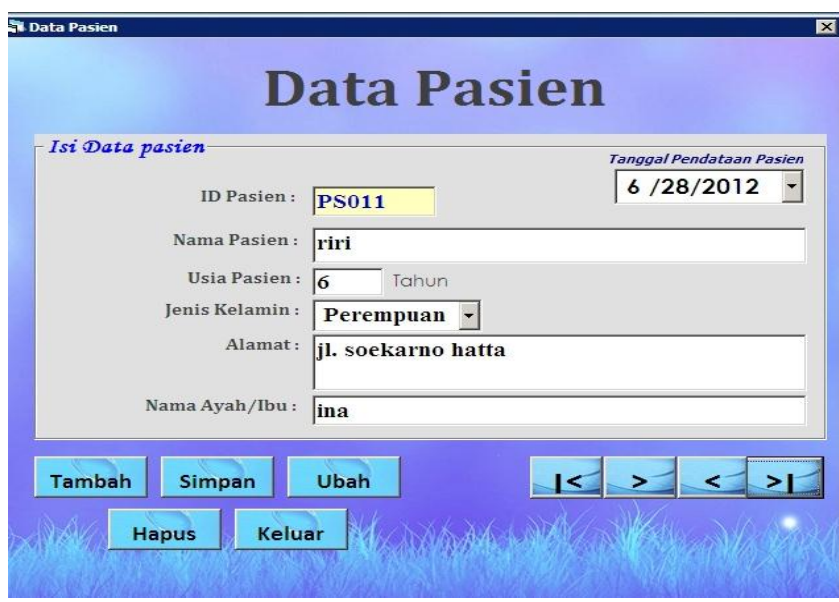

Gambar 7. Tampilan Form Pasien

\section{Form Penulusuran Gejala}

Berfungsi untuk gejala berfungsi untuk menelusuri gejala gangguan perilaku abnormal yang dirasakan pasien.

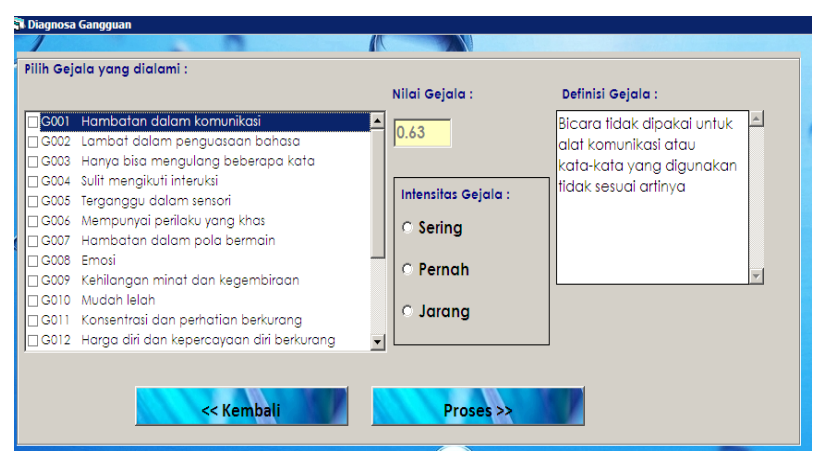

Gambar 8. Tampilan Penuluran Gejala

\section{Form Hasil Diagnosa}

Form hasil diagnosa berfungsi untuk menampilkan data gangguan perilaku abnormal dan besaran persentasi bayes

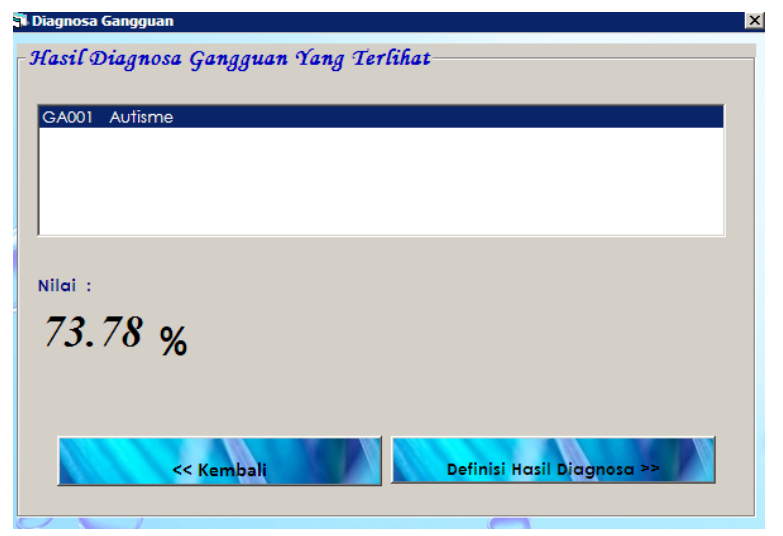

Gambar 9. Tampilan Form Hasil Diagnosa 


\section{Form Definisi dan solusi gangguan}

Form Definisi dan solusi gangguan ini berfungsi untuk menampilkan keterangan atau penjelasan dari kemungkinan gangguan yang diderita dan solusi atau cara penanganannya

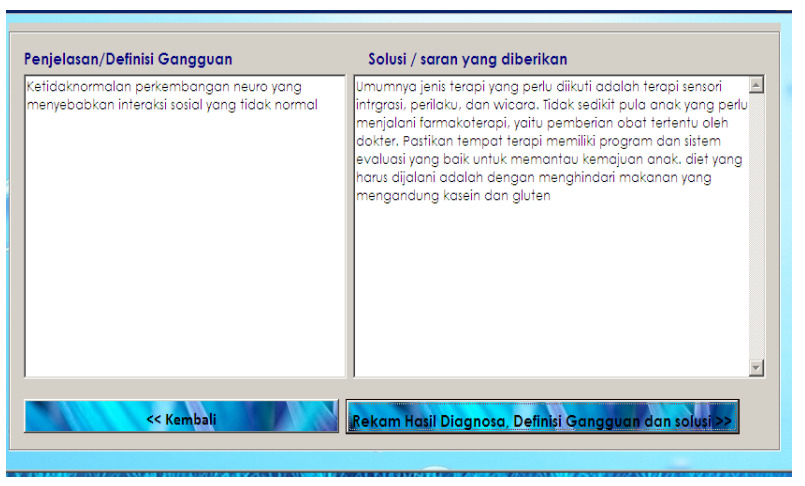

Gambar 10. Tampilan Form Definisi dan solusi gangguan

\section{Form Diagnosa}

Form diagnosa brerfungsi untuk menampung data pasien jenis gejala, hasil diagnosa dan solusinya

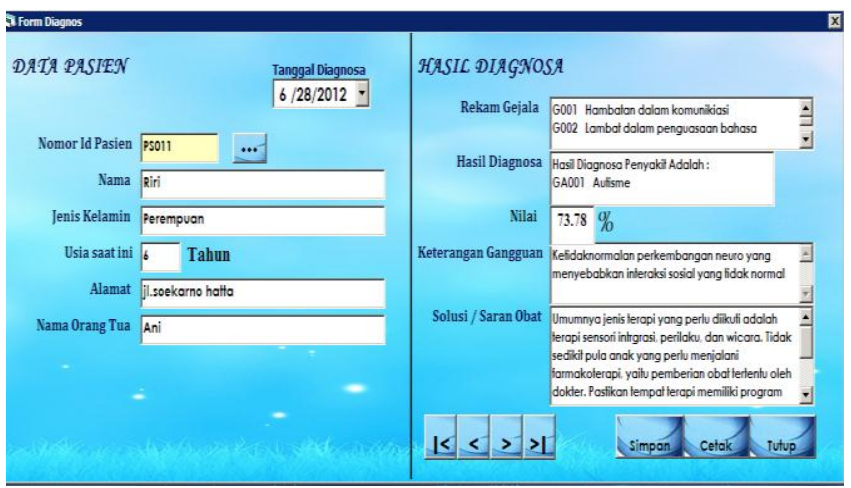

Gambar 11. Tampilan Form Diagnosa

\section{KESIMPULAN}

Dari hasil penelitian dan pembahasan yang dilakukan serta sesuai dengan tujuan dari penelitian ini, maka penulis dapat ditarik kesimpulan sebagai berikut :

1. Mampu memberikan informasi kepada user mengenai gangguan perilaku abnormal melalui gejala - gejala yang diinputkan user ke sistem sesuai dengan kondisi yang sedang dialaminya.

2. Jika dalam perkembangannya ditemukan gangguan baru atau gejala perilaku abnormal, maka aplikasi ini memfasilitasi dalam perubahan penambahan maupun penghapusan data gangguan.

3. Dengan adanya pembatasan hak akses yang diterapkan pada sistem, proses untuk pengolahan basis pengetahuan dan basis aturan hanya dapat dilakukan oleh pakar.

\section{SARAN}

Adapun saran yang dapat penulis sampaikan untuk pengembangan aplikasi sistem pakar untuk mendiagnosa kecenderungan perilaku abnormal ini adalah sebagai berikut:

1. Aplikasi ini dapat dikembangkan lebih lanjut dengan menambahkan gejala beserta solusi penanganannya sehingga dapat memberikan hasil yang lebih akurat dan terpercaya

2. Aplikasi sistem pakar untuk mendiagnosa kecenderungan perilaku abnormal ini dapat dikembangkan lebih lanjut dengan memperbaharui teknik inferensi pengetahuan pada program, sehingga sistem dapat memberikan hasil diagnosa yang lebih akurat khususnya dalam aturan/rule yang lebih bervariasi

3. Aplikasi sistem pakar untuk mendiagnosa kecenderungan perilaku abnormal ini perlu diterapkan dan juga dikembangkan secara nyata, sehingga dapat digunakan sebagaimana mestinya.

Aplikasi sistem pakar untuk mendiagnosa kecenderungan perilaku abnormal yang dibuat masih jauh dari sempurna. Karena seiring dengan bertambahnya pengetahuan seorang pakar dan berkembangnya gejala gangguan yang di timbulkan, oleh karena itu diharapkan perbaikan dan pengembangan yang lebih baik kedepannya nanti.

\section{DAFTAR PUSTAKA}

Arhami, 2004, Konsep Dasar Sistem Pakar, Andi Publiser: Yogyakarta

Fatta, Al Hanif, 2007, Analisis \& perancangan sistem informasi, ANDI, Yogyakarta: EDI

Fathansyah, 2007, Basis Data, Bandung: Informatika

Gerald C.Davision, Jhon M. Neale, Ann M. Kring, 2006, Psikology Abnormal, Edisi 9, Jakarta, PT. Rajadrafindo Persada

Jogiyanto, HM, 2003, Analisis dan Desain Sistem Informasi, Edisi kesatu, Yogyakarta: Andi Offset

Kusrini, 2008, Aplikasi Sistem Pakar, ANDI; Yogyakarta; Ed I. Komputindo kelompok gramedia; seri penuntun praktis

Kotler, Philip, 2003, Ensiklopedia Ekonomi Keuangan Perdagangan, edisi enam

M. Iqbal Hasan, 2002, Pokok-pokok materi metodologi penelitian \& aplikasinya, Ghalia Indonesia, Jakarta

Supratikya, 2008, Mengenal perilaku abnormal, kanisius, Yogyakarta

Tim divisi penelitian dan pengembangan LPKBM MADCOMS Madiun, 2006, Panduan pemrograman dan referensi kamus Visual Basic, andi offset, Yogyakarta

Ukar, Kurweni, 2007, Microsoft Office Access 2007, Jakarta: PT Elex Media Komputido KelompokGramedia, Seri penuntun praktis 